\title{
Molecular Assessment of Pathotype Diversity of Phytophthora sojae in Canada Highlights Declining Sources of Resistance in Soybean
}

\author{
Vanessa Tremblay, ${ }^{1}$ Debra L. McLaren, ${ }^{2}$ Yong Min Kim, ${ }^{2}$ Stephen E. Strelkov, ${ }^{3}$ Robert L. Conner, ${ }^{4}$ Owen Wally, ${ }^{5}$ and \\ Richard R. Bélanger ${ }^{1, \dagger}$ \\ ${ }^{1}$ Centre de Recherche en Innovation des Végétaux, Université Laval, Québec, G1V 0A6 Canada \\ ${ }^{2}$ Agriculture and Agri-Food Canada, Brandon Research and Development Centre, Brandon, Manitoba, R7A 5Y3 Canada \\ ${ }^{3}$ Department of Agricultural, Food and Nutritional Science, University of Alberta, Edmonton, Alberta, T6G 2P5 Canada \\ ${ }^{4}$ Agriculture and Agri-Food Canada, Morden Research and Development Centre, Morden, Manitoba, R6M 1Y5 Canada \\ ${ }^{5}$ Harrow Research and Development Centre, Agriculture and Agri-Food Canada, Harrow, Ontario, N0R 1G0 Canada
}

\begin{abstract}
The large-scale deployment of resistance to Phytophthora sojae (Rps) genes in soybean has led to the rapid evolution of the virulence profile (pathotype) of $P$. sojae populations. Determining the pathotypes of $P$. sojae isolates is important in selecting soybean germplasm carrying the proper Rps, but this process is fastidious and requires specific expertise. In this work, we used a molecular assay to assess the pathotypes of $P$. sojae isolates obtained throughout the provinces of Québec, Ontario, and Manitoba. In preliminary assays, the molecular tool showed equivalent prediction of the pathotypes as a phenotyping assay and proved to be much faster to apply while eliminating intermediate values. Upon

in Québec, while 1a, 1b, 1c, 1d, and 1k pathotypes were the most common in Manitoba. Overall, the results showed that 98 and $86 \%$ of the isolates carried pathotype 1a or 1c, respectively, suggesting that Rpsla and Rps1c were no longer effective in Canada. Based on the history of soybean varieties used in surveyed fields, it was found that $84 \%$ of them contained Rps genes that were no longer resistant against the pathotypes of the isolates found in the fields. While highlighting an easier and more precise option to assess pathotypes, this study presents the first pan-Canadian survey of $P$. sojae and stresses the importance of carefully managing the declining sources of resistance.
\end{abstract} analysis of nearly 300 isolates, 24 different pathotypes were detected in Québec and Ontario, compared with only eight in Manitoba, where soybean culture is more recent. Pathotypes 1a, 1c, and $1 \mathrm{~d}$ was predominant
Keywords: avirulence genes, field survey, resistance genes, root rot, soybean
Phytophthora stem and root rot (PRR), caused by the oomycete Phytophthora sojae M.J. Kaufmann and J.W. Gerdemann, was first reported in Canada by Hildebrand (1954) and accounts for approximately $\$ 50 \mathrm{M}$ in annual losses in Canadian soybean (Glycine max [L.] Merr.) production (Sepiol et al. 2017). This soilborne pathogen is particularly devastating because it can attack soybean plants at all growth stages, causing pre- and postemergence damping-off and forcing farmers to replant (Dorrance et al. 2007; Tyler 2007). It also can cause stem and root rot of established plants, constraining the water-conducting capacity of the plant, which eventually causes wilting, foliar chlorosis, and plant death (Dorrance et al. 2007; Schmitthenner 2000). Factors that contribute to PRR include poor soil drainage that can be easily flooded because of compaction, poor leveling or high clay content of the soil, and the planting of susceptible cultivars.

An effective approach to control the disease is genetic resistance (Dorrance 2018). Vertical, or total, resistance leads to complete protection against specific Phytophthora sojae isolates, conferred by single resistance genes called Rps (resistance to P. sojae; Sugimoto et al. 2012). The effectiveness of Rps genes is dependent on the presence of corresponding avirulence genes (Avr) in the pathogen (Tyler 2007) based on the classical gene-for-gene model. Gene-for-gene resistance provides complete resistance to the disease if growers use the appropriate Rps gene(s) matching the $A v r$ gene(s) present in

\section{${ }^{\dagger}$ Corresponding author: R. Bélanger; richard.belanger@fsaa.ulaval.ca}

Funding: This work was supported by the University of Alberta, the Canadian Field Crop Research Alliance, Genome Canada and Genome Québec, and the Canada Research Chairs Program.

The author(s) declare no conflict of interest.

Accepted for publication 17 June 2021.

@ 2021 The American Phytopathological Society isolates that occur in a given field. To date, $>33 \mathrm{Rps}$ genes/alleles have been identified in soybean (Jiang et al. 2020). In North America, the most common resistance genes deployed in commercial soybean lines include Rpsla, $1 c, 1 k, 3 a$, and 6 (Dorrance 2018). When a novel Rps gene is deployed into a soybean cultivar, it increases selection pressure on $P$. sojae against conserving $A v r$ genes. The pathogen avoids recognition by the Rps gene products through various mutations within their Avr genes (Arsenault-Labrecque et al. 2018; Hartman et al. 2015; Tyler and Gijzen 2014). This rapid diversification of $A v r$ genes has led to increased virulence profiles of $P$. sojae to $>200$ pathotypes (Dorrance et al. 2004) and limits the effectiveness of Rps genes over time (Grau et al. 2004; Schmitthenner 1985; Stewart et al. 2014). Because of the Avr diversification occurring within $P$. sojae, a great deal of effort has been invested in characterizing the pathotypes of $P$. sojae in soybean-producing areas to deploy the appropriate Rps genes. Plant pathologists in the U.S.A. have led the way in these endeavors with multiple race survey reports over the years, particularly in the Northern and Midwestern states including Iowa, Indiana, Illinois, Kansas, Michigan, Minnesota, Missouri, Nebraska, New York, Ohio, and North and South Dakota (Dorrance et al. 2003, 2016; Stewart et al. 2014; Yan and Nelson 2019). In Canada, where soybean production is more recent and more localized, only a few articles from the literature are available. The first survey was conducted in the 1980s in Ontario (Anderson and Buzzell 1992) and the second one, limited to Ontario again, highlighted the evolution of $P$. sojae pathotypes over two survey periods (Xue et al. 2015). Thereafter, a few reports, from the provinces of Manitoba or Alberta, provided the first description of $P$. sojae pathotypes in a limited number of fields (Chang et al. 2017; Henriquez et al. 2020). In all those surveys, the hypocotyl inoculation test, developed by Kaufmann and Gerdemann (1958), was used to phenotype $P$. sojae pathotypes. This method consists of wounding and inoculating young soybean hypocotyls of near-isogenic lines with different Rps genes with a mycelial slurry of an isolate of $P$. sojae. While this method is easy to apply, it has its shortcomings in that it is labor-intensive, can yield intermediate values, false-positives and 
false-negatives, and bypasses the natural method of zoospore infection of the root system (Lebreton et al. 2018). To alleviate these limitations, another assay was proposed in which inoculation took place in a hydroponic system to better recreate the natural course of infection (Lebreton et al. 2018). While providing a more accurate determination of the pathotypes (Arsenault-Labrecque et al. 2018), the assay remains laborious and time-consuming. In 2020, a molecular tool for predicting the pathotypes of $P$. sojae was developed by Dussault-Benoit et al. (2020). This molecular tool was designed based on genomic analyses in which haplotypes of $A v r$ genes could be assigned to virulent or avirulent forms for seven $A v r$ genes or alleles: Avrla, $1 b, 1 c, 1 d, 1 k, 3 a$, and 6 (Arsenault-Labrecque et al. 2018). This assay provides a relatively rapid and accurate identification of the virulence profile of many $P$. sojae isolates simultaneously.

In this study, the general objective was to conduct the first comprehensive pan-Canadian analysis of $P$. sojae pathotypes in the major soybean-growing areas of the country. For this purpose, the molecular assay was first validated against the hydroponic phenotypic assay, and then exploited to analyze hundreds of $P$. sojae isolates and to relate the information in terms of pathotype distribution/evolution and management practices.

\section{Materials and Methods}

Field sampling. Soil samples were collected across Québec, Ontario, and Manitoba during the 2016 to 2019 growing seasons. These provinces account for $96 \%$ of the soybean production area in Canada, with 16\% in Québec, 57\% in Ontario, and 23\% in Manitoba (Soy Canada 2020). The majority of soybean fields in Ontario and Québec were selected for sampling based on a history of PRR or a history of stand establishment problems, while in Manitoba the fields were selected randomly. Samples from Québec were collected from 71 commercial soybean fields, six experimental soybean fields, and four disease nurseries. Samples from Ontario were taken from 75 commercial soybean fields, five experimental soybean fields, and one disease nursery. Samples from Manitoba were taken from 84 commercial soybean fields. At least three soil cores were taken by sites where soybean plants with PRR symptoms were observed or in compaction zones. The soil samples $(\sim 1 \mathrm{~kg})$ were taken at a depth of $15 \mathrm{~cm}$ from the rhizosphere using a shovel. The soil samples were airdried and stored at $4^{\circ} \mathrm{C}$ until pathogen isolation. Whenever possible, in Québec and Manitoba, information on the cultivar planted in the sampled fields was collected for association studies between $P$. sojae pathotypes recovered and Rps genes used in the soybean cultivars.

Baiting procedures and isolation of $\boldsymbol{P}$. sojae. The soybean seedling bioassay procedure (baiting method) described by Canaday and Schmitthenner (1982) was used to isolate P. sojae from soil. Each soil sample was placed in a 415-ml plastic cup, flooded for $24 \mathrm{~h}$ with distilled water, and then allowed to dry slowly in the dark at room temperature until the soil began to pull away from the sides of the glass. Cups were then closed with a lid for 2 weeks until planting. After incubation, five seeds of the soybean variety 'Sloan' or 'Williams' (susceptible to all known races of $P$. sojae) were planted and covered with a fine layer of vermiculite. The cups were placed inside a growth chamber set at $26^{\circ} \mathrm{C}$ day and $16^{\circ} \mathrm{C}$ night under a photoperiod of $13 \mathrm{~h}$ per day illuminated with incandescent and fluorescent $(590 \mu \mathrm{Mol}$ light). After seed germination, the cups were flooded again for $24 \mathrm{~h}$ and then allowed to dry. Soybean plants were monitored for evidence of typical PPR symptoms, including root lesions or hypocotyl collapse, for 7 to 14 days. To isolate the pathogen, tissue sections $(1 \mathrm{~cm})$ cut from the margin of lesions on hypocotyls were surface-disinfested by submersion in $70 \%$ ethanol for $10 \mathrm{~s}$, rinsed in sterilized distilled water and air-dried. The outer layer of the stem was removed very carefully, and the central tissues were sectioned into $0.5-\mathrm{cm}$ pieces and placed on the semiselective V8 PBNIC agar medium containing Terrachlor (99\% pentachloronitrobenzene; Sigma-Aldrich, St. Louis, MO) at $0.04 \mathrm{~g} \mathrm{liter}^{-1}$, Benlate (50\% benomyl; Sigma-Aldrich) at $0.01 \mathrm{~g} \mathrm{liter}^{-1}$, neomycin sulfate at $0.05 \mathrm{~g} \mathrm{liter}^{-1}$, Rovral (50\% iprodione; Bayer Cropscience, Montvale, $\mathrm{NJ})$ at $0.04 \mathrm{~g} \mathrm{liter}^{-1}$, and chloramphenicol at $0.1 \mathrm{~g} \mathrm{liter}^{-1}$ in a V8 juice agar base (200 $\mathrm{ml} \mathrm{liter}^{-1}$ of clarified V8 juice; Campbell Soup
Co., Camden, NJ), and $15 \mathrm{~g} \mathrm{liter}^{-1}$ agar. To decrease bacterial growth, the medium was flipped to relocate the pieces between the bottom of the plate and the medium, and the Petri dishes were incubated at $28^{\circ} \mathrm{C}$ for 1 week. Petri dishes were monitored daily for presence of the pathogen. On the semiselective medium, $P$. sojae was easily identifiable by its creamy-white cottony appearance on the root tissues. If no growth of $P$. sojae was observed, the baiting steps were repeated twice. Hyphal tips of $P$. sojae growing from infected tissues were transferred onto regular V8 medium $\left(200 \mathrm{ml} \mathrm{liter}^{-1}\right.$ of clarified V8 juice and $15 \mathrm{~g} \mathrm{liter}^{-1}$ agar).

Single-spore isolation. A single-spore isolate was recovered by oospore isolation. Briefly, a 7-to-10-day-old culture from a 5-ml Petri dish containing V8 Phytagel medium (rifampicin $0.1 \mathrm{~g} \mathrm{liter}^{-1}$; Sigma-Aldrich), Phytagel (4 $\left.\mathrm{g} \mathrm{liter}^{-1}\right)$, and clarified V8 $(200 \mathrm{ml}$ liter $^{-1}$ ) was blended with $30 \mathrm{ml}$ of sterile water in a commercial blender for $10 \mathrm{~s}$. The mixture was poured into a $50-\mathrm{ml}$ sterile tube. The tube was placed on ice and kept at $4^{\circ} \mathrm{C}$ for $24 \mathrm{~h}$ to kill mycelium. The tube was centrifuged $(1 \mathrm{~m}, 3,200 \mathrm{RCF})$ and decanted to separate the medium and the mycelium from the pellet containing the oospores. Thirty milliliters of water were added to the tube, vortexed, centrifuged, and decanted a second time. The pellet was diluted to a concentration of 10 oospores $/ \mathrm{ml}$ and $200 \mu \mathrm{l}$ of the oospore suspension was spread on regular V8 agar medium. The oospores were incubated at $28^{\circ} \mathrm{C}$ and began to germinate after $24 \mathrm{~h}$. Germinated oospores were transferred onto regular V8 agar using a sterile needle under a stereomicroscope (60× magnification).

DNA extraction and molecular pathotype characterization. The single-spore isolates were subcultured on regular V8 agar medium covered with cellulose paper to facilitate the harvest of hyphae and spores. After 7 days, isolates were removed from the paper and placed in $1.5-\mathrm{ml}$ tubes containing two porcelain beads $(2.8 \mathrm{~mm})$. The samples were homogenized $\left(4 \mathrm{~m} \mathrm{~s}^{-1} \times 2\right.$ cycles of $30 \mathrm{~s}$ with a 40-s pause) with an Omni Bead Ruptor 24 (OMNI International, Tulsa, OK) and the DNA was then extracted using a cetyltrimethyl-ammonium bromide procedure (Werth et al. 2016).

The molecular assay allowed verification that the isolates recovered were $P$. sojae, because it is highly specific and also permitted the identification of the pathotype of each isolate using two PCR reactions following Dussault-Benoit et al. (2020). The first reaction was a multiplex PCR allowing simultaneous amplification of Avrla, Avrlb, Avrld, Avrlk, Avr3a, and Avr6; the second reaction amplified Avrlc. The multiplex PCR cocktail contained $1.5 \mu \mathrm{l}$ of a mix of eight primer sets and the uniplex reaction contained only one primer set at a concentration described by Dussault-Benoit et al. (2020), $0.5 \mu \mathrm{l}$ of $10 \mathrm{mM}$ dNTPs, $0.1 \mu \mathrm{l}$ of OneTaq DNA polymerase $(5,000$ units/ml; New England Biolabs, Ipswich, MA), and $4 \mu \mathrm{l}$ of $5 \times$ OneTaq Standard Reaction Buffer to which was added $2 \mu \mathrm{l}$ of $10 \mathrm{ng} / \mu \mathrm{l}$ DNA and sterile distilled water to a final volume of $20 \mu \mathrm{l}$. All reactions were performed in a $\mathrm{T}$ Professional Thermocycler (Biometra, Göttingen, Germany), using 40 cycles for the multiplex reaction and 30 cycles for the uniplex reaction. The thermal cycling settings consisted of an initial denaturation at $94^{\circ} \mathrm{C}$ for 5 min, cycles of denaturation at $94^{\circ} \mathrm{C}$ for $30 \mathrm{~s}$, annealing for $30 \mathrm{~s}$ at $55^{\circ} \mathrm{C}$ for the multiplex PCR or $60^{\circ} \mathrm{C}$ for the uniplex PCR, extension at $68^{\circ} \mathrm{C}$ for $1 \mathrm{~min}$, and a final extension at $68^{\circ} \mathrm{C}$ for $5 \mathrm{~min}$.

Hydroponic pathotype characterization. To assess the validity and the precision of the molecular assay, a subsample of 18 isolates was arbitrarily chosen and also analyzed using a modified version of the hydroponic bioassay developed by Lebreton et al. (2018). The bioassay involved the inoculation of a panel of soybean differentials provided by Dr. Owen Wally (Harrow Research and Development Centre, Agriculture and Agri-Food Canada, Harrow, ON, Canada) possessing different Rps genes ('Haro12' [Rps1a], 'Haro13' [Rps1b], 'Haro14' [Rpslc], 'Haro16' [Rps1d], 'Haro15' [Rps1k], 'Haro3272' $[R p s 3 a, 7]$, and 'Haro6272' [Rps6, 7]) with an isolate of $P$. sojae. Soybean seeds were sown in sterile vermiculite and the plantlets were transferred into the hydroponic system containing the nutritive solution 5 days' postseeding. Twenty-four hours after the transfer of the plants, the hydroponic system was inoculated with the isolate of $P$. sojae. The inoculum was prepared by blending two 12-day-old cultures from 20-ml Petri dishes containing V8 Phytagel medium 
with $60 \mathrm{ml}$ of sterile water in a commercial blender. The resulting mycelial slurry was examined under a microscope $(100 \times)$ to adjust the oospore concentration. Subsequently, the hydroponic system was inoculated with $1 \times 10^{6}$ oospores. Each isolate of $P$. sojae was characterized in two independent experiments $(n=4$ plants per Rps). At 14 days postinoculation, plants were scored as resistant or susceptible to the isolate according to the method presented in Dussault-Benoit et al. (2020).

\section{Results}

Phytophthora sojae isolation. A total of 246 fields was sampled during the 2016 to 2019 seasons, including 81 in Québec, 81 in Ontario, and 84 in Manitoba. Altogether, 295 separate single-spore isolates of $P$. sojae were obtained originating as follows: 92 from Québec, 96 from Ontario, and 107 from Manitoba.

Molecular versus hydroponic assay. The DNA of the 295 single-spore isolates was extracted and then characterized by the molecular assay. This tool predicted the virulence profile of the isolates based on the amplification of seven avirulence genes for Avrla, $1 b, 1 c, 1 d, 1 k, 3 a$, and 6 . To assess the validity and the precision of this assay, a subsample of 18 isolates was also analyzed using the hydroponic bioassay made up of a panel of the different Rps genes that were challenged with a given isolate. The results obtained indicated a high level of consistency between the two methods (Table 1 ), wherein the genotyping approach matched the results of the phenotyping approach in 72 out of 76 alleles (95\%). Interestingly, all four cases of disparity involved an additional virulence allele in the phenotyping approach, most of which (three out of four) were associated with Avr3a.

Pathotype diversity. After characterization of the 295 isolates with the molecular tool, 31 unique virulence formula or pathotype combinations based on the seven Avr genes were detected (Table 2). Some pathotype combinations were more common than others. For instance, pathotypes 1a, 1b, 1c, 1d, and 1k represented $34 \%$ of $P$. sojae isolates analyzed, and pathotypes $1 \mathrm{a}, 1 \mathrm{c}$, and $1 \mathrm{~d}$ represented $25 \%$. Pathotypes 1a and 1c were found in $6 \%$ of isolates. All other combinations were found in percentages of $<5 \%$.

Pathotype distribution and complexity by province. In Québec, 24 different pathotype combinations were detected and pathotypes 1a, 1c, and 1d was predominant, representing $29 \%$ of the isolates characterized (Table 2), followed by pathotypes $1 \mathrm{a}, 1 \mathrm{~b}, 1 \mathrm{c}, 1 \mathrm{~d}$, and $1 \mathrm{k}$ with a prevalence of $13 \%$. In this province, the complex of pathotypes, expressed by the number of virulent alleles, predominantly involved three alleles (Fig. 1). Only a few isolates harbored more than five virulence alleles, while a complex of four alleles was found in approximately $10 \%$ of the isolates.
In Ontario, 23 pathotype combinations were detected. Pathotypes $1 \mathrm{a}, 1 \mathrm{~b}, 1 \mathrm{c}, 1 \mathrm{~d}$, and $1 \mathrm{k}$ were predominant, comprising $23 \%$ of the isolates, followed by pathotypes $1 \mathrm{a}, 1 \mathrm{c}$, and $1 \mathrm{~d}$, which accounted for $21 \%$ of the isolates (Fig. 1). The complex of pathotypes also mostly included three alleles with almost $40 \%$, followed by approximately $20 \%$ of the isolates with five alleles. Thereafter, smaller percentages were associated with lower and higher virulence allele numbers.

Only eight pathotype combinations were observed in Manitoba. Pathotypes $1 \mathrm{a}, 1 \mathrm{~b}, 1 \mathrm{c}, 1 \mathrm{~d}$, and $1 \mathrm{k}$ were predominant, representing $62 \%$ of the isolates, followed by pathotypes $1 \mathrm{a}, 1 \mathrm{c}$, and $1 \mathrm{~d}$ representing $25 \%$ of the isolates (Fig. 1). As in Québec and Ontario, the

Table 2. Molecular assessment of pathotypes of 295 isolates of Phytophthora sojae recovered from soybean fields in Québec, Ontario, and Manitoba between 2016 and 2019

\begin{tabular}{lrcrrr}
\hline Pathotypes & Québec & Ontario & Manitoba & Total & \% \\
\hline 1a & 2 & 9 & 0 & 11 & 4 \\
1a, 1b, 1c & 1 & 5 & 0 & 6 & 2 \\
1a, 1b, 1c, 1d & 1 & 1 & 0 & 2 & 1 \\
1a, 1b, 1c, 1d, 1k & 12 & 22 & 66 & 100 & 34 \\
1a, 1b, 1c, 1d, 1k, 3a, 6 & 1 & 1 & 0 & 2 & 1 \\
1a, 1b, 1c, 1d, 1k, 6 & 2 & 0 & 0 & 2 & 1 \\
1a, 1b, 1c, 1k & 2 & 3 & 5 & 10 & 3 \\
1a, 1b, 1c, 3a, 6 & 0 & 1 & 0 & 1 & 0 \\
1a, 1b, 1d, 1k & 1 & 0 & 0 & 1 & 0 \\
1a, 1b, 1k & 1 & 4 & 0 & 5 & 2 \\
1a, 1b, 3a, 6 & 0 & 1 & 0 & 1 & 0 \\
1a, 1c 1c 1d & 8 & 8 & 1 & 17 & 6 \\
1a, 1c, 1d 1d, 1k & 27 & 20 & 27 & 74 & 25 \\
1a, 1c, 1, 1d, 1k, 3a, 6 & 1 & 0 & 1 & 2 & 1 \\
1a, 1c, 1d, 3a & 0 & 1 & 0 & 1 & 0 \\
1a, 1c, 1d, 3a & 1 & 0 & 4 & 5 & 2 \\
1a, 1c, 1d, 3a, 6 & 4 & 1 & 2 & 7 & 2 \\
1a, 1c, 1d, 6 & 1 & 0 & 1 & 2 & 1 \\
1a, 1c, 3a & 0 & 1 & 0 & 1 & 0 \\
1a, 1c, 3a, 6 & 3 & 1 & 0 & 4 & 1 \\
1a, 1c, 6 & 5 & 1 & 0 & 6 & 2 \\
1a, 1d & 1 & 2 & 0 & 3 & 1 \\
1a, 1d, 6 & 0 & 1 & 0 & 1 & 0 \\
1a, 3a & 2 & 0 & 0 & 2 & 1 \\
1a, 3a, 6 & 2 & 0 & 13 & 4 \\
1a, 6 & 2 & 5 & 0 & 7 & 2 \\
1b, 1c, 1d, 1k & 1 & 0 & 0 & 1 & 0 \\
1b, 1c, 1d, 3a & 0 & 1 & 0 & 1 & 0 \\
1b, 1c, 1k & 1 & 2 & 0 & 3 & 1 \\
1c & 1 & 0 & 0 & 1 & 0 \\
1c, 1d & 3 & 0 & 3 & 1 \\
Total & 96 & 107 & 295 & 100 \\
\hline & & & &
\end{tabular}

Table 1. Characterization of the pathotypes of 18 isolates of Phytophthora sojae from Québec, Ontario, and Manitoba with the hydroponic bioassay (phenotype) and with the molecular tool (genotype)

\begin{tabular}{|c|c|c|c|}
\hline \multirow[b]{2}{*}{ Province } & \multicolumn{3}{|c|}{ Pathotypes $^{\mathrm{a}}$} \\
\hline & Identification & Phenotype & Genotype \\
\hline \multirow[t]{6}{*}{ Québec } & Ps_0762 & $1 \mathrm{a}, 1 \mathrm{~b}, 1 \mathrm{c}, 1 \mathrm{~d}, 1 \mathrm{k}, 6$ & $1 \mathrm{a}, 1 \mathrm{~b}, 1 \mathrm{c}, 1 \mathrm{~d}, 1 \mathrm{k}, 6$ \\
\hline & Ps_0802 & $1 \mathrm{a}, 1 \mathrm{~b}, 1 \mathrm{c}, 1 \mathrm{k}$ & $1 \mathrm{a}, 1 \mathrm{~b}, 1 \mathrm{c}, 1 \mathrm{k}$ \\
\hline & Ps_0768 & $1 \mathrm{a}, 1 \mathrm{c}, 1 \mathrm{~d}$ & $1 \mathrm{a}, 1 \mathrm{c}, 1 \mathrm{~d}$ \\
\hline & Ps_0584 & $1 \mathrm{a}, 1 \mathrm{c}, 1 \mathrm{~d}, 1 \mathrm{k}$ & $1 \mathrm{a}, 1 \mathrm{c}, 1 \mathrm{~d}, 1 \mathrm{k}$ \\
\hline & Ps_0767 & $1 \mathrm{a}, 1 \mathrm{c}, 1 \mathrm{~d}, 3 \mathrm{a}, 6$ & $1 \mathrm{a}, 1 \mathrm{c}, 1 \mathrm{~d}, 3 \mathrm{a}, 6$ \\
\hline & Ps_0781 & $1 \mathrm{a}, 1 \mathrm{c}, 3 \mathrm{a}^{\mathrm{b}}, 6$ & $1 \mathrm{a}, 1 \mathrm{c}, 6$ \\
\hline \multirow[t]{6}{*}{ Ontario } & Ps_0604 & $1 \mathrm{a}, 1 \mathrm{~b}, 1 \mathrm{c}, 1 \mathrm{~d}$ & $1 \mathrm{a}, 1 \mathrm{~b}, 1 \mathrm{c}, 1 \mathrm{~d}$ \\
\hline & Ps_0627 & $1 \mathrm{a}, 1 \mathrm{~b}, 1 \mathrm{c}, 1 \mathrm{~d}, 1 \mathrm{k}$ & $1 \mathrm{a}, 1 \mathrm{~b}, 1 \mathrm{c}, 1 \mathrm{~d}, 1 \mathrm{k}$ \\
\hline & Ps_0639 & $1 \mathrm{a}, 1 \mathrm{c}^{\mathrm{b}}$ & $1 \mathrm{a}$ \\
\hline & Ps_0685 & $1 \mathrm{a}, 1 \mathrm{c}, 1 \mathrm{~d}$ & $1 \mathrm{a}, 1 \mathrm{c}, 1 \mathrm{~d}$ \\
\hline & Ps_0703 & $1 \mathrm{a}, 1 \mathrm{c}, 1 \mathrm{~d}, 3 \mathrm{a}, 6$ & $1 \mathrm{a}, 1 \mathrm{c}, 1 \mathrm{~d}, 3 \mathrm{a}, 6$ \\
\hline & Ps_0722 & $1 \mathrm{a}, 1 \mathrm{c}, 3 \mathrm{a}^{\mathrm{b}}, 6$ & $1 \mathrm{a}, 1 \mathrm{c}, 6$ \\
\hline \multirow[t]{6}{*}{ Manitoba } & Ps_0476 & $1 \mathrm{a}, 1 \mathrm{~b}, 1 \mathrm{c}, 1 \mathrm{~d}, 1 \mathrm{k}$ & $1 \mathrm{a}, 1 \mathrm{~b}, 1 \mathrm{c}, 1 \mathrm{~d}, 1 \mathrm{k}$ \\
\hline & Ps_0492 & $1 \mathrm{a}, 1 \mathrm{~b}, 1 \mathrm{c}, 1 \mathrm{~d}, 1 \mathrm{k}$ & $1 \mathrm{a}, 1 \mathrm{~b}, 1 \mathrm{c}, 1 \mathrm{~d}, 1 \mathrm{k}$ \\
\hline & Ps_0539 & $1 \mathrm{a}, 1 \mathrm{~b}, 1 \mathrm{c}, 1 \mathrm{~d}, 1 \mathrm{k}, 3 \mathrm{a}^{\mathrm{b}}$ & $1 \mathrm{a}, 1 \mathrm{~b}, 1 \mathrm{c}, 1 \mathrm{~d}, 1 \mathrm{k}$ \\
\hline & Ps_0591 & $1 \mathrm{a}, 1 \mathrm{c}, 1 \mathrm{~d}$ & $1 \mathrm{a}, 1 \mathrm{c}, 1 \mathrm{~d}$ \\
\hline & Ps_0444 & $1 \mathrm{a}, 1 \mathrm{c}, 1 \mathrm{~d}, 3 \mathrm{a}$ & $1 \mathrm{a}, 1 \mathrm{c}, 1 \mathrm{~d}, 3 \mathrm{a}$ \\
\hline & Ps_0515 & $1 \mathrm{a}, 1 \mathrm{c}, 1 \mathrm{~d}, 6$ & $1 \mathrm{a}, 1 \mathrm{c}, 1 \mathrm{~d}, 6$ \\
\hline
\end{tabular}

\footnotetext{
${ }^{a}$ Although $A v r 7$ was not included in the genotype test, pathotype 7 was recorded in all isolates subjected to the hydroponic assay

${ }^{\mathrm{b}}$ Indicates presence of a virulence allele with the phenotyping approach that was absent with the genotyping approach.
} 
dominance of three and five virulence alleles was caused by the fact that $1 \mathrm{~b}$ and $1 \mathrm{k}$ tended to be present or absent in tandem in all isolates analyzed.

Virulence allele distribution. Virulence on Rpsla was detected in 96, 94, and $100 \%$ of $P$. sojae tested from Québec, Ontario, and Manitoba, respectively (Fig. 2). This was followed closely by pathotypes that were virulent on the resistance allele Rps $1 \mathrm{c}$, representing 77,75 , and $100 \%$ of the isolates, respectively.

Virulence on Rps $1 k$ was present only in 16 and $33 \%$ of the isolates from Québec and Ontario, respectively. This percentage rose to $67 \%$ in isolates from Manitoba. Virulence on Rps $1 b$ followed the same pattern as Rps $1 k$ in all provinces. Virulence on Rps 3 a and 6 was observed occasionally, particularly in Manitoba, with the exception of virulence on Rps6, which occurred in 30\% of the isolates in Québec. Finally, considering that Rps1d is not commercially deployed, it was rather surprising to find isolates virulent on this genotype in 50\% of the collections from Québec and Ontario and $90 \%$ in those from Manitoba.

Pathotypes versus Rps genes in field. During the course of these surveys, whenever possible, the identity of the soybean variety in the sampled fields was recorded. This information was available for 64 fields in Québec, where 87 isolates of $P$. sojae were recovered, and for 30 fields in Manitoba, where 49 isolates were collected. No such information was obtained in Ontario. As shown in Figure 3, Rpslc was the most common resistance gene deployed, followed by Rpslk, Rpsla, and Rps3a, while nearly one-third of the fields were planted with cultivars carrying no Rps genes.

Tables 3 and 4 present a comprehensive comparison between the $P$. sojae pathotypes found in a given field and the Rps genes used in that field. As expected, for all fields where Rpsla was used, all $P$. sojae isolates recovered had the corresponding pathotype 1a. A very similar association was observed for Rpslc, where in $96 \%$ of the cases, the isolates were pathotype $1 \mathrm{c}$, resulting in a compatible

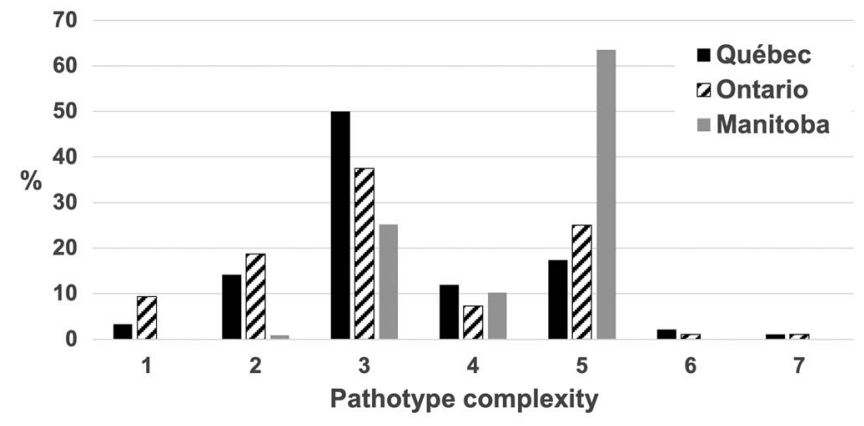

Fig. 1. Percentage of Phytophthora sojae isolates carrying a given pathotype complexity based on virulence genes avr $1 a, 1 b, 1 c, 1 d, 1 k$, 3a, and 6 . The percentage is based on 295 isolates of $P$. sojae recovered in Québec, Ontario, and Manitoba fields in 2018 and 2019.

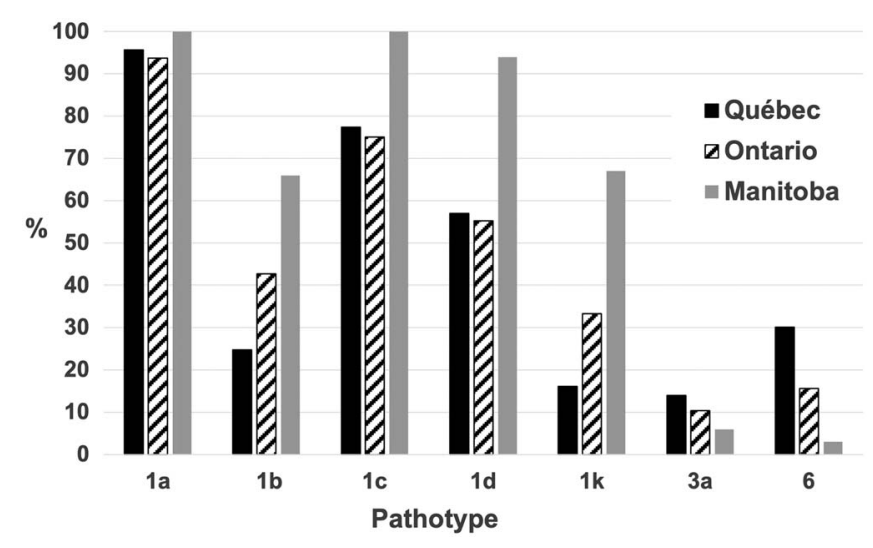

Fig. 2. Percentage of Phytophthora sojae isolates carrying a given pathotype. The percentage is based on 295 isolates of $P$. sojae recovered in Québec, Ontario, and Manitoba fields in 2018 and 2019. interaction. These predicted compatible reactions were somewhat less common in fields where Rpslk, Rps3a, or Rps6 were used as sources of resistance. Nevertheless, in both Québec and Manitoba, $>80 \%$ of the sampled fields used soybean varieties that were not resistant to the $P$. sojae pathotypes present in the fields.

\section{Discussion}

With the rapid expansion of soybean production in Canada, $P$. sojae arguably has become the most an important limiting factor in its production. For this reason, a greater awareness of the pathotype diversity of this pathogen must be taken into consideration when applying genetic approaches to manage the disease. This study reports findings of the first pan-Canadian survey of the genetic complexity of $P$. sojae isolates in soybean fields across the provinces of Québec, Ontario, and Manitoba, where 96\% of soybean production occurs. To carry out these analyses, $P$. sojae pathotypes were assessed based on a molecular test by Dussault-Benoit et al. (2020), which allowed greater ease, speed, and accuracy in determining the virulence formula of the tested isolates. This exhaustive characterization of $P$. sojae should help soybean growers, breeders, and seed suppliers in making educated decisions when deploying Rps genes for the purpose of reducing losses to PRR.

Historically, all studies that have analyzed the pathotype diversity of $P$. sojae isolates have relied on the hypocotyl assay, which involves testing single isolates on a set of soybean differentials carrying different Rps genes and alleles. This method is both time- and labor-intensive, and also is prone to yielding false positives or negatives when intermediate responses occur. While the hydroponic assay developed by Lebreton et al. (2018) may be more accurate, it remains as fastidious as the hypocotyl assay. For this reason, the molecular assay used in this study represents an important breakthrough in pathotype studies, because it is much less demanding in terms of time, space, and manpower. It is also theoretically more accurate, as amplification of the virulence genes is less open to interpretation. When comparing the molecular assay with the hydroponic method, this study demonstrated that a high level of consistency among $95 \%$ of the alleles studied. Interestingly, the most common, albeit infrequent, discrepancy was related to Avr3a. In their description of the molecular assay, Dussault-Benoit et al. (2020) also observed that results for Avr3a were sometimes at odds with the

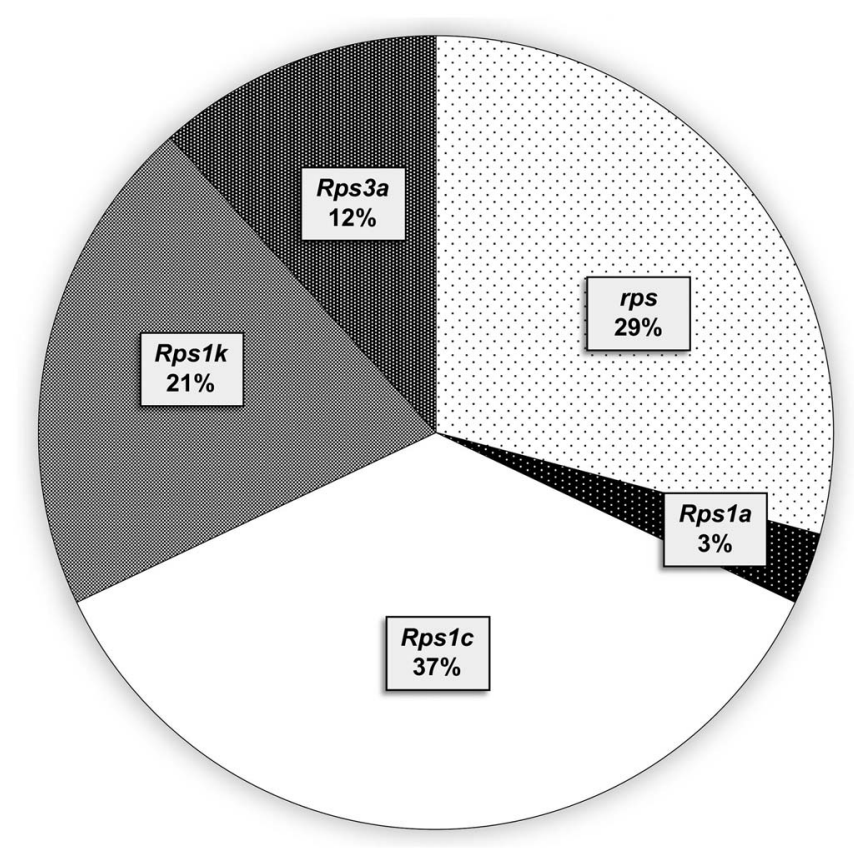

Fig. 3. Relative field distribution of different Rps genes present in soybean cultivars in 64 and 30 fields in the provinces of Québec and Manitoba, respectively, sampled for the presence of Phytophthora sojae in 2018 to 2019. Pyramiding of Rps genes in some cultivars explain total exceeding $100 \%$. 
hydroponic assay, while Arsenault-Labrecque et al. (2018) reported a perfect match between the molecular assay and the hypocotyl assay for detecting Avr3a. This may simply indicate that the hydroponic assay is sometimes too stringent for allowing the timely expression of Rps3a. Nevertheless, the results of this study suggest that the molecular assay is, on many levels, a significant advance for the easy and rapid assessment of $P$. sojae pathotypes.

Overall, the pathotype combination 1a, 1c, and 1d was the most common across all three provinces. Regardless of the diversity, nearly all isolates analyzed were virulent against Rpsla genotypes, and the vast majority were also virulent on Rpslc genotypes. These results might be explained by the fact that Rps $1 a$ and Rps $1 c$ were the first resistance genes deployed commercially in soybean in Canada, and that selection pressure has led to an increase in the prevalence of virulence for these genes (Jackson et al. 2004; Schmitthenner et al. 1994). This study clearly indicates that $P$. sojae has overcome those resistance genes and that good resistance stewardship practices are necessary to preserve the other ones.

An unexpected finding in the course of our surveys was the frequent detection of some pathotypes with virulence on Rpsla, Rpslb, $R p s 1 c, R p s 1 d$, and Rpslk, especially in Manitoba. Incidentally, there was a much higher percentage of isolates with pathotypes $1 \mathrm{~b}$ and $1 \mathrm{k}$ in that province than in Ontario and Québec. This was surprising because expansion of the cultivation of short-season soybeans capable of growing in Manitoba has occurred predominantly within the past 10 years. A possible explanation is that Rpslk has been heavily deployed in Manitoba in adapted varieties, while being more gradually integrated in the Québec or Ontario production areas. The deployment of newer Rps genes such as Rpslk in commercial soybean cultivars has contributed to the emergence of new pathotypes with increased complexity (Xue et al. 2015). This situation also was reported in the USA (Dorrance et al. 2016; Jackson et al. 2004; Yan and Nelson 2019) and Argentina (Grijalba et al. 2020). It is also interesting to observe how the presence of the virulence or avirulence alleles of $1 \mathrm{~b}$ and $1 \mathrm{k}$ were nearly always synchronized and also reported in other studies (Whisson et al. 1995). This suggests that a more thorough characterization of Rps $1 b$ and Rpslk should be conducted to explain this phenomenon.

A fairly large number of $P$. sojae isolates were shown to possess virulence on Rpsld, although the corresponding resistance gene has not been deployed commercially in soybean varieties in Canada. This observation has been reported in other soybean-growing regions in the USA, where isolates were virulent on Rps genes that were not known to be deployed in the region (Dorrance et al. 2016; Jackson et al. 2004; Schmitthenner et al. 1994; Stewart et al. 2014).

The only information regarding the occurrence of $P$. sojae pathotypes, dating as far back to the 1980s, is from Ontario, which was the first province to invest in soybean research. Two large-scale

Table 3. Association between the pathotypes of Phytophthora sojae isolates in a soybean field and the Rps genes present in the cultivar used in the field for 87 isolates from Québec

\begin{tabular}{|c|c|c|c|c|c|c|c|}
\hline \multicolumn{8}{|c|}{ Québec } \\
\hline ID & Pathotype & Rps & Expected response & ID & Pathotype & Rps & Expected response \\
\hline Ps_0545 & $1 \mathrm{a}, 1 \mathrm{~d}$ & - & Disease & Ps_0727 & $1 \mathrm{a}, 1 \mathrm{c}$ & $1 \mathrm{c}$ & Disease \\
\hline Ps_0573 & $1 \mathrm{a}, 6$ & - & Disease & Ps_0744 & $1 \mathrm{c}$ & $1 \mathrm{c}$ & Disease \\
\hline Ps_0547 & $1 \mathrm{a}, 1 \mathrm{c}, 1 \mathrm{~d}, 1 \mathrm{k}$ & - & Disease & Ps_0745 & $1 \mathrm{a}, 1 \mathrm{c}, 1 \mathrm{~d}$ & $1 \mathrm{c}$ & Disease \\
\hline Ps_0728 & $1 \mathrm{a}, 3 \mathrm{a}$ & - & Disease & Ps_0730 & $1 \mathrm{a}, 1 \mathrm{c}$ & $1 \mathrm{c}$ & Disease \\
\hline Ps_0549 & $1 \mathrm{a}, 1 \mathrm{c}, 3 \mathrm{a}, 6$ & - & Disease & Ps_0544 & $1 \mathrm{a}, 1 \mathrm{c}, 1 \mathrm{~d}$ & $1 \mathrm{c}$ & Disease \\
\hline Ps_0550 & $1 \mathrm{a}, 1 \mathrm{c}$ & - & Disease & Ps_0732 & $1 \mathrm{a}, 1 \mathrm{~b}, 1 \mathrm{c}, 1 \mathrm{~d}, 1 \mathrm{k}$ & $1 \mathrm{c}$ & Disease \\
\hline Ps_0731 & $1 \mathrm{a}, 3 \mathrm{a}$ & - & Disease & Ps_0733 & $1 \mathrm{a}, 1 \mathrm{~b}, 1 \mathrm{c}, 1 \mathrm{k}$ & $1 \mathrm{c}$ & Disease \\
\hline Ps_0552 & $1 \mathrm{a}$ & - & Disease & Ps_0734 & $1 \mathrm{~b}, 1 \mathrm{c}, 1 \mathrm{k}$ & $1 \mathrm{c}$ & Disease \\
\hline Ps_0544 & $1 \mathrm{a}, 3 \mathrm{a}, 6$ & - & Disease & Ps_0735 & $1 \mathrm{a}, 1 \mathrm{c}, 1 \mathrm{~d}$ & $1 \mathrm{c}$ & Disease \\
\hline Ps_0554 & $1 \mathrm{a}, 1 \mathrm{c}, 1 \mathrm{~d}$ & - & Disease & Ps_0746 & $1 \mathrm{a}, 1 \mathrm{c}, 1 \mathrm{~d}$ & $1 \mathrm{c}$ & Disease \\
\hline Ps_0555 & $1 \mathrm{a}, 1 \mathrm{c}, 1 \mathrm{~d}$ & - & Disease & Ps_0737 & $1 \mathrm{a}, 1 \mathrm{~b}, 1 \mathrm{c}, 1 \mathrm{~d}, 1 \mathrm{k}$ & $1 \mathrm{c}$ & Disease \\
\hline Ps_0739 & $1 \mathrm{a}, 1 \mathrm{c}, 1 \mathrm{~d}$ & - & Disease & Ps_0738 & $1 \mathrm{a}, 1 \mathrm{c}, 6$ & $1 \mathrm{c}$ & Disease \\
\hline Ps_0570 & $1 \mathrm{a}, 1 \mathrm{c}, 1 \mathrm{~d}, 3 \mathrm{a}, 6$ & - & Disease & Ps_0546 & $1 \mathrm{a}, 1 \mathrm{c}, 1 \mathrm{~d}$ & $1 \mathrm{c}$ & Disease \\
\hline Ps_0558 & $1 \mathrm{a}, 1 \mathrm{c}, 6$ & - & Disease & Ps_0551 & $1 \mathrm{a}, 1 \mathrm{~b}, 1 \mathrm{c}, 1 \mathrm{~d}, 1 \mathrm{k}$ & $1 \mathrm{c}$ & Disease \\
\hline Ps_0559 & $1 \mathrm{a}, 1 \mathrm{~b}, 1 \mathrm{c}, 1 \mathrm{~d}, 1 \mathrm{k}$ & - & Disease & Ps_0560 & $1 \mathrm{a}, 1 \mathrm{c}, 1 \mathrm{~d}, 3 \mathrm{a}, 6$ & $1 \mathrm{c}$ & Disease \\
\hline Ps_0729 & $1 \mathrm{a}, 1 \mathrm{~b}, 1 \mathrm{c}, 1 \mathrm{~d}, 1 \mathrm{k}$ & - & Disease & Ps_0747 & $1 \mathrm{a}, 1 \mathrm{c}, 1 \mathrm{~d}$ & $1 \mathrm{c}$ & Disease \\
\hline Ps_0561 & $1 \mathrm{a}, 1 \mathrm{c}, 1 \mathrm{~d}$ & - & Disease & Ps_0548 & $1 \mathrm{a}, 1 \mathrm{c}, 6$ & $1 \mathrm{c}$ & Disease \\
\hline Ps_0562 & $1 \mathrm{a}, 1 \mathrm{c}, 1 \mathrm{~d}$ & - & Disease & Ps_0748 & $1 \mathrm{a}, 1 \mathrm{c}, 1 \mathrm{~d}$ & $1 \mathrm{c}$ & Disease \\
\hline Ps_0736 & $1 \mathrm{a}, 1 \mathrm{c}, 1 \mathrm{~d}, 3 \mathrm{a}$ & - & Disease & Ps_0749 & $1 \mathrm{a}, 1 \mathrm{c}, 1 \mathrm{~d}, 3 \mathrm{a}, 6$ & $1 \mathrm{c}$ & Disease \\
\hline Ps_0564 & $1 \mathrm{a}, 1 \mathrm{c}$ & - & Disease & Ps_0750 & $1 \mathrm{a}, 1 \mathrm{c}$ & $1 \mathrm{c}$ & Disease \\
\hline Ps_0565 & $1 \mathrm{a}, 1 \mathrm{c}, 6$ & - & Disease & Ps_0751 & $1 \mathrm{a}, 1 \mathrm{c}, 1 \mathrm{~d}$ & $1 \mathrm{k}$ & Disease \\
\hline Ps_0739 & $1 a, 3 a, 6$ & - & Disease & Ps_0563 & $1 \mathrm{a}, 1 \mathrm{~b}, 1 \mathrm{c}, 1 \mathrm{~d}, 1 \mathrm{k}$ & $1 \mathrm{k}$ & Disease \\
\hline Ps_0740 & $1 \mathrm{a}, 1 \mathrm{~b}, 1 \mathrm{c}, 1 \mathrm{k}$ & - & Disease & Ps_0557 & $1 \mathrm{a}, 1 \mathrm{~b}, 1 \mathrm{c}, 1 \mathrm{~d}, 1 \mathrm{k}$ & $1 \mathrm{k}$ & Disease \\
\hline Ps_0568 & $1 \mathrm{a}, 1 \mathrm{c}, 1 \mathrm{~d}$ & - & Disease & Ps_0752 & $1 \mathrm{~b}, 1 \mathrm{c}, 1 \mathrm{~d}, 1 \mathrm{k}$ & $1 \mathrm{k}$ & Disease \\
\hline Ps_0569 & $1 \mathrm{a}, 1 \mathrm{c}, 1 \mathrm{~d}$ & - & Disease & Ps_0774 & $1 \mathrm{a}, 3 \mathrm{a}, 6$ & $1 \mathrm{k}$ & Resistance \\
\hline Ps_0741 & $1 \mathrm{a}, 1 \mathrm{c}, 1 \mathrm{~d}$ & $1 \mathrm{a}$ & Disease & Ps_0775 & $1 \mathrm{a}, 1 \mathrm{c}, 1 \mathrm{~d}$ & $1 \mathrm{k}$ & Resistance \\
\hline Ps_0571 & $1 \mathrm{a}, 3 \mathrm{a}, 6$ & $1 \mathrm{a}$ & Disease & Ps_0753 & $1 \mathrm{a}, 1 \mathrm{c}, 6$ & $1 \mathrm{k}$ & Resistance \\
\hline Ps_0572 & $1 \mathrm{a}, 1 \mathrm{c}, 1 \mathrm{~d}$ & $1 \mathrm{a}$ & Disease & Ps_0553 & $1 \mathrm{a}, 6$ & $1 \mathrm{k}$ & Resistance \\
\hline Ps_0742 & $1 a, 3 a, 6$ & $1 \mathrm{a}$ & Disease & Ps_0556 & $1 \mathrm{a}, 1 \mathrm{~b}, 1 \mathrm{c}$ & $1 \mathrm{k}$ & Resistance \\
\hline Ps_0574 & $1 \mathrm{a}, 1 \mathrm{c}, 3 \mathrm{a}, 6$ & $1 \mathrm{c}$ & Disease & Ps_0754 & $1 \mathrm{a}, 1 \mathrm{~b}, 1 \mathrm{c}, 1 \mathrm{~d}$ & $1 \mathrm{k}$ & Resistance \\
\hline Ps_0755 & $1 \mathrm{a}, 1 \mathrm{c}, 1 \mathrm{~d}$ & $1 \mathrm{c}$ & Disease & Ps_0762 & $1 \mathrm{a}, 1 \mathrm{~b}, 1 \mathrm{c}, 1 \mathrm{~d}, 1 \mathrm{k}, 6$ & $1 \mathrm{k}$ & Disease \\
\hline Ps_0756 & $1 \mathrm{a}, 1 \mathrm{c}, 1 \mathrm{~d}$ & $1 \mathrm{c}$ & Disease & Ps_0763 & $1 \mathrm{a}, 1 \mathrm{~b}, 1 \mathrm{c}, 1 \mathrm{~d}, 1 \mathrm{k}$ & $1 \mathrm{k}$ & Disease \\
\hline Ps_0771 & $1 \mathrm{a}, 3 \mathrm{a}, 6$ & $1 \mathrm{c}$ & Resistance & Ps_0764 & $1 a, 3 a, 6$ & $1 \mathrm{k}$ & Resistance \\
\hline Ps_0772 & $1 \mathrm{a}, 1 \mathrm{c}, 1 \mathrm{~d}$ & $1 \mathrm{c}$ & Disease & Ps_0566 & $1 \mathrm{a}, 1 \mathrm{c}$ & $1 k+3 a$ & Resistance \\
\hline Ps_0757 & $1 \mathrm{a}, 1 \mathrm{~b}, 1 \mathrm{c}, 1 \mathrm{~d}, 1 \mathrm{k}$ & $1 \mathrm{c}$ & Disease & Ps_0567 & $1 \mathrm{a}, 1 \mathrm{~b}, 1 \mathrm{k}$ & $1 k+3 a$ & Resistance \\
\hline Ps_0758 & $1 \mathrm{a}, 1 \mathrm{~b}, 1 \mathrm{c}, 1 \mathrm{~d}, 1 \mathrm{k}$ & $1 \mathrm{c}$ & Disease & Ps_0765 & $1 \mathrm{a}, 3 \mathrm{a}, 6$ & $3 a$ & Disease \\
\hline Ps_0759 & $1 \mathrm{a}, 1 \mathrm{c}, 1 \mathrm{~d}$ & $1 \mathrm{c}$ & Disease & Ps_0766 & $1 \mathrm{a}, 3 \mathrm{a}, 6$ & $3 a$ & Disease \\
\hline Ps_0760 & $1 \mathrm{a}, 1 \mathrm{c}, 1 \mathrm{~d}, 6$ & $1 \mathrm{c}$ & Disease & Ps_0767 & $1 \mathrm{a}, 1 \mathrm{c}, 1 \mathrm{~d}, 3 \mathrm{a}, 6$ & $3 a$ & Disease \\
\hline Ps_0761 & $1 \mathrm{a}, 1 \mathrm{c}, 1 \mathrm{~d}$ & $1 \mathrm{c}$ & Disease & Ps_0776 & $1 \mathrm{a}, 1 \mathrm{c}, 3 \mathrm{a}, 6$ & $3 a$ & Disease \\
\hline Ps_0773 & $1 \mathrm{a}, 1 \mathrm{~b}, 1 \mathrm{c}, 1 \mathrm{~d}, 1 \mathrm{k}$ & $1 \mathrm{c}$ & Disease & Ps_0777 & $1 \mathrm{a}$ & $3 a$ & Resistance \\
\hline Ps_0778 & $1 \mathrm{a}, 1 \mathrm{~b}, 1 \mathrm{c}, 1 \mathrm{~d}, 1 \mathrm{k}, 6$ & $1 \mathrm{c}$ & Disease & Ps_0768 & $1 \mathrm{a}, 1 \mathrm{c}, 1 \mathrm{~d}$ & $3 a$ & Resistance \\
\hline Ps_0779 & $1 \mathrm{a}, 1 \mathrm{~b}, 1 \mathrm{c}, 1 \mathrm{~d}, 1 \mathrm{k}$ & $1 \mathrm{c}$ & Disease & Ps_0769 & $1 a, 3 a, 6$ & $3 a$ & Disease \\
\hline Ps_0780 & $1 \mathrm{a}, 1 \mathrm{c}$ & $1 \mathrm{c}$ & Disease & Ps_0770 & $1 \mathrm{a}, 1 \mathrm{~b}, 1 \mathrm{c}, 1 \mathrm{~d}, 1 \mathrm{k}, 3 \mathrm{a}, 6$ & $3 a$ & Disease \\
\hline \multicolumn{2}{|c|}{ Total of isolates $=87$} & \multicolumn{2}{|c|}{ Disease $=86 \%$} & \multicolumn{4}{|c|}{ Resistance $=14 \%$} \\
\hline
\end{tabular}


studies were previously conducted, the first by Anderson and Buzzell (1992), which reported on the different "races" of $P$. sojae in the 80 s and the second by Xue et al. (2015), which reported similar results from the early 2010s. Those studies provide an important window into the evolution of $P$. sojae pathotypes over time for a given region (Table 5). The first striking feature is that the first study described 10 races, while the second study reported 23 races, which represented a considerable increase. According to Xue et al. (2015), pathotype complexity in Ontario has increased, involving one to five alleles in the 1980s versus two to eight in 2010. Because the complexity of the pathotypes in this study was determined on the basis of seven Avr genes with the molecular tool, a direct comparison was limited as $A v r 7$ is not part of the molecular assay. It can be inferred from the two previous studies, however, that all the isolates in this study carried virulence for Rps 7 because it was the first Rps gene to be deployed (Xue et al. 2015). On the other hand, an increase in the complexity of the pathotypes obtained in this study was found in comparison with earlier investigations. Indeed, over time, pathotypes 1a and 7 have become rare, while more complex pathotypes such as 1a, 1c, 7 and 1a, 1c, 1d, 7 have appeared. Pathotypes 1a and 7 decreased from $25.1 \%$ in the report of Anderson and Buzzell (1992) to 12\% in the report of Xue et al. (2015), to just $9.4 \%$ in this study. Pathotype $1 \mathrm{k}$ was quite prevalent in both our study and that of Xue et al. (2015), but was conspicuously absent in the survey by Anderson and Buzzell (1992). These results demonstrate that pathotype diversification is driven by selection pressure from Rps genes, because Rpslk was only deployed in Ontario after the initial survey.

Based on this last statement, it seems contradictory to observe the increasing presence over time of virulence for Rpsld, reaching 23\% in this study. This may indicate that Rpsld has been deployed unknowingly in certain commercial soybean varieties, as has been reported for Rps6 (Anderson et al. 2007; Athow and Laviolette 1982). Additionally, some studies have found a significant percentage of isolates with virulence on Rps1d (Dorrance et al. 2016; Stewart et al. 2014), thus supporting the unknown presence of Rpsld in some soybean varieties.

Henriquez et al. (2020) characterized the pathotypes of some P. sojae isolates from Manitoba collected in 2014, 2016, and 2017 using the hypocotyl test. Their results were fairly similar to this study, with the notable exception that $>90 \%$ of our isolates carried virulence for Rpsld, while nearly none did in the former study. Based on the results of this study, this may indicate that issues existed with the Rpsld differential used in that study, a problem previously reported among differentials of a similar gene in other studies (Dorrance et al. 2004). In as much as the presence of the avirulence gene will lead to an incompatible reaction, as shown in an overwhelming percentage in previous papers (Arsenault-Labrecque et al. 2018; Dussault-Benoit et al. 2020), the molecular assay can thus eliminate the bias owing to the differential source.

To our knowledge, this is the first study in Canada reporting on $P$. sojae pathotypes that has a direct association with the Rps genes present in soybean varieties in sampled fields. Admittedly, although sampling in Québec in this study was biased toward fields with a suspected presence of PRR, sampling in Manitoba was arbitrary and the results indicated, in both provinces, a high percentage of fields using soybean varieties with an inappropriate Rps gene for the pathotypes found in the field. Rpsla was the first resistance gene to be widely deployed and, according to the results in this study, it is, for all practical purposes, no longer effective, because most isolates have acquired virulence against Rpsla; but $5 \%$ of the fields surveyed still relied on that gene to manage Phytophthora stem and root rot. More troublesome is the fact that Rpslc has become almost as obsolete, but was still used in $30 \%$ of the fields. This information should serve as a warning to farmers and seed suppliers to alter their selection and introgression of Rps genes. In this context, some soybean growers did opt for varieties with other Rps such as Rps $1 k, 3 a$, and 6 , which appeared to fare better. It is worrisome to note, though, that almost $70 \%$ of the isolates from Manitoba carry virulence for $R p s 1 k$, and this leaves Rps3a and Rps6 - which are often less frequently available in suppliers' catalogs - as the sole effective options.

Whereas the effectiveness of Rps1a appeared to last nearly 40 years (Schmitthenner 1972; Schwenk and Slim 1974), Rps genes deployed in more recent years seem to have had a much shorter lifespan (Dorrance et al. 2016). This reality was highlighted in this study, along with the need to better manage the available sources of resistance. In addition, the development of new molecular tools, such as the assay employed here, allows for much faster, easier, and more precise analysis of evolving pathotypes, providing information that can be exploited in disease management and associated decision-

Table 4. Association between the pathotypes of Phytophthora sojae isolates in a soybean field and the Rps genes present in the cultivar used in the field for 49 isolates from Manitoba

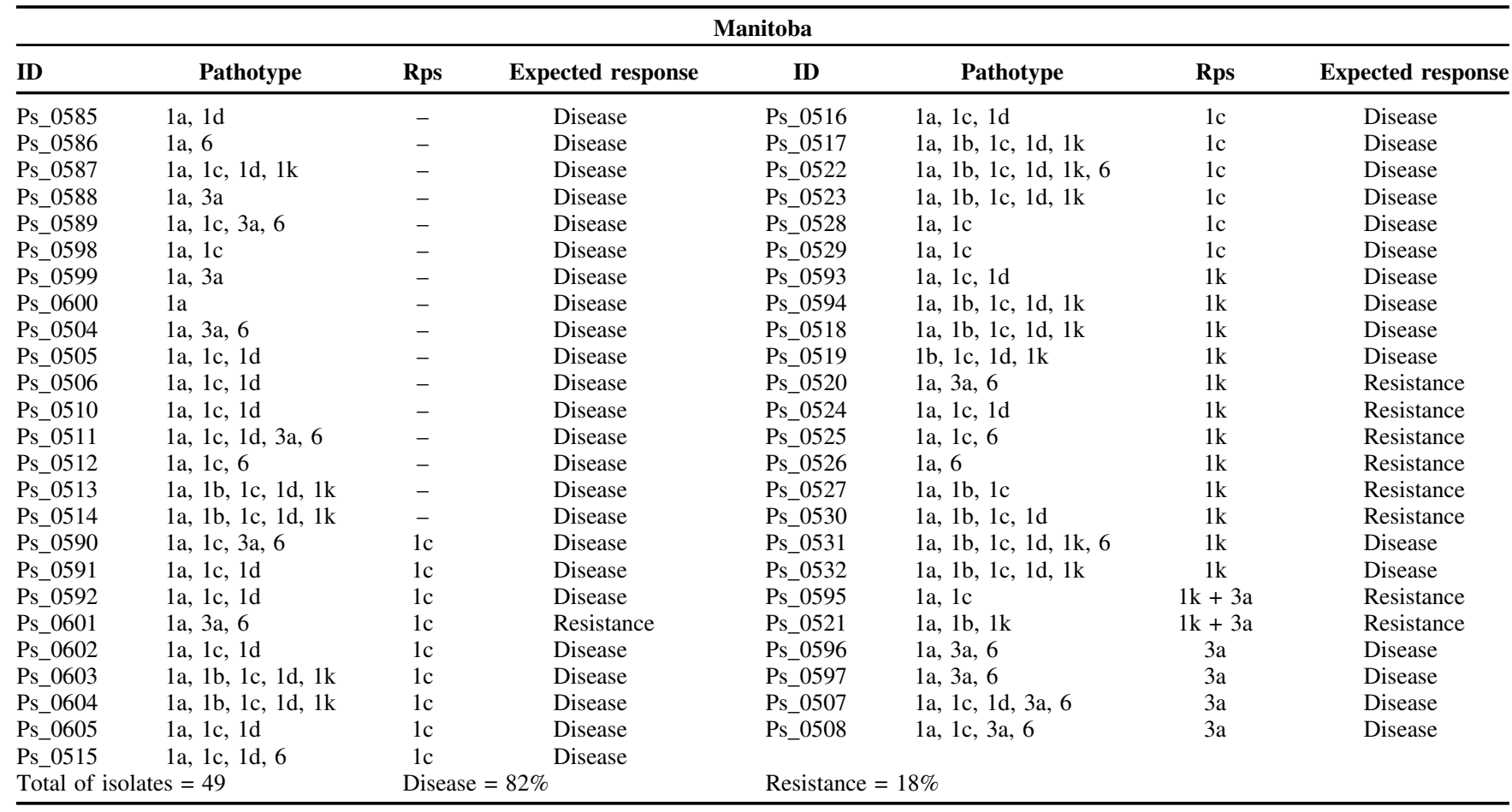


Table 5. Comparison of the evolution of relative pathotype diversity of isolates of Phytophthora sojae collected in Ontario over three survey periods

\begin{tabular}{|c|c|c|c|}
\hline \multirow[b]{2}{*}{ Pathotype $^{\text {a }}$} & \multicolumn{3}{|c|}{$\%$ of Isolates } \\
\hline & 2018 to 2019 & 2010 to $2012^{b}$ & 1980 to $1989^{c}$ \\
\hline $1 \mathrm{a}, 7$ & 9.4 & 12 & 25.1 \\
\hline 1a $1 \mathrm{c}, 6,7$ & 1.0 & 9.0 & 3.9 \\
\hline $1 \mathrm{a}, 1 \mathrm{~b}, 1 \mathrm{c}, 7$ & 5.2 & 0.0 & 0.0 \\
\hline $1 \mathrm{a}, 1 \mathrm{~b}, 1 \mathrm{c}, 1 \mathrm{~d}, 7$ & 1.0 & 0.0 & 0.0 \\
\hline $1 \mathrm{a}, 1 \mathrm{~b}, 1 \mathrm{c}, 1 \mathrm{~d}, 1 \mathrm{k}, 7$ & 22.9 & 0.0 & 0.0 \\
\hline $1 \mathrm{a}, 1 \mathrm{~b}, 1 \mathrm{c}, 1 \mathrm{~d}, 1 \mathrm{k}, 3 \mathrm{a}, 6,7$ & 0.0 & 0.8 & 0.0 \\
\hline $1 \mathrm{a}, 1 \mathrm{~b}, 1 \mathrm{c}, 1 \mathrm{k}, 7$ & 3.1 & 14.3 & 0.0 \\
\hline $1 \mathrm{a}, 1 \mathrm{~b}, 1 \mathrm{c}, 1 \mathrm{k}, 3 \mathrm{a}, 7$ & 0.0 & 0.6 & 0.0 \\
\hline $1 \mathrm{a}, 1 \mathrm{~b}, 1 \mathrm{c}, 1 \mathrm{k}, 3 \mathrm{a}, 6,7$ & 0.0 & 0.6 & 0.0 \\
\hline $1 \mathrm{a}, 1 \mathrm{~b}, 1 \mathrm{c}, 1 \mathrm{k}, 6,7$ & 0.0 & 5.0 & 0.0 \\
\hline $1 \mathrm{a}, 1 \mathrm{~b}, 1 \mathrm{c}, 3 \mathrm{a}, 6,7$ & 1.0 & 0.0 & 0.0 \\
\hline 1a, $1 \mathrm{~b}, 1 \mathrm{k}, 7$ & 4.2 & 6.7 & 0.0 \\
\hline $1 \mathrm{a}, 1 \mathrm{~b}, 1 \mathrm{k}, 3 \mathrm{a}, 6,7$ & 0.0 & 2.2 & 0.0 \\
\hline $1 \mathrm{a}, 1 \mathrm{~b}, 1 \mathrm{k}, 6,7$ & 0.0 & 1.1 & 0.0 \\
\hline $1 \mathrm{a}, 1 \mathrm{~b}, 3 \mathrm{a}, 6,7$ & 1.0 & 0.0 & 0.0 \\
\hline $1 \mathrm{a}, 1 \mathrm{~b}, 6,7$ & 0.0 & 0.3 & 0.0 \\
\hline $1 \mathrm{a}, 1 \mathrm{c}, 7$ & 8.3 & 8.7 & 13.9 \\
\hline $1 \mathrm{a}, 1 \mathrm{c}, 1 \mathrm{~d}, 7$ & 20.8 & 0.8 & 0.0 \\
\hline $1 \mathrm{a}, 1 \mathrm{c}, 1 \mathrm{~d}, 1 \mathrm{k}, 3 \mathrm{a}, 6,7$ & 1.0 & 0.0 & 0.0 \\
\hline $1 \mathrm{a}, 1 \mathrm{c}, 1 \mathrm{~d}, 3 \mathrm{a}, 6,7$ & 1.0 & 0.0 & 0.0 \\
\hline $1 \mathrm{a}, 1 \mathrm{c}, 3 \mathrm{a}, 7$ & 1.0 & 0.0 & 0.0 \\
\hline $1 \mathrm{a}, 1 \mathrm{c}, 3 \mathrm{a}, 6,7$ & 1.0 & 2.0 & 0.3 \\
\hline $1 \mathrm{a}, 1 \mathrm{~d}, 7$ & 2.1 & 0.0 & 0.0 \\
\hline $1 \mathrm{a}, 1 \mathrm{~d}, 3 \mathrm{a}, 6,7$ & 0.0 & 5.3 & 0.2 \\
\hline $1 \mathrm{a}, 1 \mathrm{~d}, 6,7$ & 1.0 & 5.0 & 0.2 \\
\hline $1 \mathrm{a}, 1 \mathrm{k}, 7$ & 0.0 & 1.1 & 0.0 \\
\hline 1a, 3a, 7 & 0.0 & 0.0 & 0.3 \\
\hline 1a, 3a, 6,7 & 2.1 & 6.2 & 33.6 \\
\hline $1 a, 6,7$ & 5.2 & 9.5 & 14.4 \\
\hline $1 \mathrm{~b}, 1 \mathrm{c}, 1 \mathrm{~d}, 1 \mathrm{k}, 3 \mathrm{a}, 6,7$ & 1.0 & 3.1 & 0.0 \\
\hline $1 \mathrm{~b}, 1 \mathrm{c}, 1 \mathrm{~d}, 3 \mathrm{a}, 7$ & 1.0 & 0.0 & 0.0 \\
\hline $1 \mathrm{~b}, 1 \mathrm{c}, 1 \mathrm{k}, 7$ & 2.1 & 0.0 & 0.0 \\
\hline $1 \mathrm{~b}, 1 \mathrm{~d}, 3 \mathrm{a}, 6,7$ & 0.0 & 0.6 & 0.0 \\
\hline $1 \mathrm{c}, 7$ & 0.0 & 2.0 & 0.0 \\
\hline $1 \mathrm{c}, 1 \mathrm{~d}, 7$ & 3.1 & 0.0 & 0.0 \\
\hline $1 c, 6,7$ & 0.0 & 0.3 & 0.0 \\
\hline 6,7 & 0.0 & 0.3 & 1.0 \\
\hline 7 & 0.0 & 0.8 & 0.0 \\
\hline
\end{tabular}

${ }^{\text {a }}$ Data for 2018 to 2019; pathotype 7 was deemed present on all isolates through phenotyping.

${ }^{\mathrm{b}}$ Data from Xue et al. (2015).

${ }^{\mathrm{c}}$ Data from Anderson and Buzzell (1992).

making. Thus, soybean growers, breeders, and seed suppliers will be better positioned to make science-based choices in their efforts to curb losses caused by $P$. sojae.

\section{Acknowledgments}

The authors acknowledge the technical support of Waldo C. Penner and Dennis B. Stoesz of the Morden Research Centre; of Tom Henderson, Maria Antonia Henriquez, and Teri Kerley of the Brandon Research Centre; of Ashley Wragg of the Harrow Research Centre; and Amandine Lebreton, Sidonie Paredones, and Jean-Philippe Moreau of the Université Laval.

\section{Literature Cited}

Anderson, T. R., and Buzzell, R. I. 1992. Diversity and frequency of races of Phytophthora megasperma f. sp. glycinea in soybean fields in Essex County, Ontario, 1980-1989. Plant Dis. 76:587-589.

Anderson, T. R., Buzzell, R. I., Voldeng, H. D., and Poysa, V. 2007. Evaluation of short season soybean cultivars for Rps6 resistance to Phytophthora sojae. Soybean Genet. Newsl. 34:1-4.

Arsenault-Labrecque, G., Sonah, H., Lebreton, A., Labbé, C., Marchand, G., Xue, A., Belzile, F., Knaus, B. J., Grünwald, N. J., and Bélanger, R. R. 2018. Stable predictive markers for Phytophthora sojae avirulence genes that impair infection of soybean uncovered by whole genome sequencing of 31 isolates. BMC Biol. 16:80.

Athow, K. L., and Laviolette, F. A. 1982. Rps6, a major gene for resistance to Phytophthora megasperma f. sp. glycinea in soybean. Phytopathology 72: 1564-1567.
Canaday, C. H., and Schmitthenner, A. F. 1982. Isolating Phytophthord megasperma f. sp. glycinea from soil with a baiting method that minimizes Pythium contamination. Soil Biol. Biochem. 14:67-68.

Chang, K. F., Hwang, S. F., Ahmed, H. U., Zhou, Q., Strelkov, S. E., Conner, R. L., McLaren, D. L., Henriquez, M. A., Harding, M. W., and Turnbull, G. D. 2017. First report of Phytophthora sojae causing root rot in soybean [Glycine max (L.) Merr.] in Alberta, Canada. Crop Prot. 91:49-56.

Dorrance, A. E. 2018. Management of Phytophthora sojae of soybean: a review and future perspectives. Can. J. Plant Pathol. 40:210-219.

Dorrance, A. E., Jia, H., and Abney, T. S. 2004. Evaluation of soybean differentials for their interaction with Phytophthora sojae. Plant Health Prog. 5:9.

Dorrance, A. E., Kurle, J., Robertson, A. E., Bradley, C. A., Giesler, L., Wise, K., and Concibido, V. C. 2016. Pathotype diversity of Phytophthora sojae in eleven states in the United States. Plant Dis. 100:1429-1437.

Dorrance, A. E., McClure, S. A., and deSilva, A. 2003. Pathogenic diversity of Phytophthora sojae in Ohio soybean fields. Plant Dis. 87:139-146.

Dorrance, A. E., Mills, D., Robertson, A. E., Draper, M. A., Giesler, L., and Tenuta, A. 2007. Phytophthora root and stem rot of soybean. The Plant Health Instructor. doi: 10.1094/PHI-I-2007-0830-07.

Dussault-Benoit, C., Arsenault-Labrecque, G., Sonah, H., Belzile, F., and Bélanger, R. R. 2020. Discriminant haplotypes of avirulence genes of Phytophthora sojae lead to a molecular assay to predict phenotypes. Mol. Plant Pathol. 21:318-329.

Grau, C. R., Dorrance, A. E., Russin, J. S., and Bond, J. 2004. Fungal diseases Pages 679-763 in: Soybeans: Improvement, Production, and Uses, 3rd Ed H. R. Boerma, and J. E. Specht, eds. American Society of Agronomy, Crop Science Society of America, and Soil Science Society of America, Madison, WI.

Grijalba, P. E., Ridao, A. D. C., Guillin, E., and Steciow, M. 2020. Pathogenic diversity of Phytophthora sojae in the southeast of the Province of Buenos Aires. Trop. Plant Pathol. 45:397-401.

Hartman, G. L., Rupe, J. C., Sikora, E. J., Domier, L. L., Davis, J. A., and Steffey, K. L. 2015. Compendium of Soybean Diseases and Pests, 5th Ed American Phytopathological Society, St. Paul, MN.

Henriquez, M. A., Kim, Y. M., McLaren, D. L., Conner, R. L., Xue, A. Marchand, G., Yu, K., Chang, K. F., Hwang, S. F., Strelkov, S. E., and Gossen, B. D. 2020. First report on the pathotype diversity of Phytophthora sojae in Manitoba, Canada. Crop Prot. 137:105236.

Hildebrand, A. A. 1954. Diseases of soybeans in southwestern Ontario in 1954. Can. Plant Dis. Surv. 34:45-48

Jackson, T. A., Kirkpatrick, T. L., and Rupe, J. C. 2004. Races of Phytophthora sojae in Arkansas soybean fields and their effects on commonly grown soybean cultivars. Plant Dis. 88:345-351.

Jiang, B., Cheng, Y., Cai, Z., Li, M., Jiang, Z., Ma, R., Yuan, Y., Xia, Q. and Nian, H. 2020. Fine mapping of a Phytophthora-resistance locus RpsGZ in soybean using genotyping-by-sequencing. BMC Genomics 21: 280.

Kaufmann, J. J., and Gerdemann, J. Q. 1958. Root rot of soybeans caused by Phytophthora sojae n. sp. Phytopathology 48:201-208.

Lebreton, A., Labbé, C., De Ronne, M., Xue, A. G., Marchand, G., and Bélanger, R. R. 2018. Development of a simple hydroponic assay to study vertical and horizontal resistance of soybean and pathotypes of Phytophthora sojae. Plant Dis. 102:114-123.

Schmitthenner, A. F. 1972. Evidence for a new race of Phytophthora megasperma var. sojae pathogenic to soybean. Plant Dis. Rep. 56:536-539.

Schmitthenner, A. F. 2000. Phytophthora rot of soybean. Plant Health Prog. $1: 13$.

Schmitthenner, A. F. 1985. Problems and progress in control of Phytophthora root rot of soybean. Plant Dis. 69:362-368.

Schmitthenner, A. F., Hobe, M., and Bhat, R. G. 1994. Phytophthora sojae races in Ohio over a 10-year interval. Plant Dis. 78:269-276.

Schwenk, F. W., and Slim, T. 1974. Race four of Phytophthora megasperma var. sojae from soybeans proposed. Plant Dis. Rep. 58:352-354.

Sepiol, C. J., Yu, J., and Dhaubhadel, S. 2017. Genome-wide identification of chalcone reductase gene family in soybean: insight into root-specific GmCHRs and Phytophthora sojae resistance. Front. Plant Sci. 8:2073.

Soy Canada. 2020. Acres Canadian soybean seeded acres (1980 to current). https://soycanada.ca/statistics/seeded-area-acres/

Stewart, S., Abeysekara, N., and Robertson, A. E. 2014. Pathotype and genetic shifts in a population of Phytophthora sojae under soybean cultivar rotation. Plant Dis. 98:614-624.

Sugimoto, T., Kato, M., Yoshida, S., Matsumoto, I., Kobayashi, T., Kaga, A., Hajika, M., Yamamoto, R., Watanabe, K., Aino, M., Matoh, T., Walker, D. R., Biggs, A. R., and Ishimoto, M. 2012. Pathogenic diversity of Phytophthora sojae and breeding strategies to develop Phytophthora-resistant soybeans. Breed. Sci. 61:511-522.

Tyler, B. M. 2007. Phytophthora sojae: root rot pathogen of soybean and model oomycete. Mol. Plant Pathol. 8:1-8.

Tyler, B. M., and Gijzen, M. 2014. The Phytophthora sojae genome sequence: Foundation for a revolution. Pages 133-157 in: Genomics of Plant-Associated Fungi and Oomycetes: Dicot Pathogens. R. A Dean, A. Lichens-Park, and C. Kole, eds. Springer, Heidelberg, Berlin, Germany. 
Werth, S., Reynisdóttir, S., Gudmundsson, H., and Andrésson, O. S. 2016. A fast and inexpensive high-throughput protocol for isolating high molecular weight genomic DNA from lichens. Herzogia 29:610-616.

Whisson, S. C., Drenth, A., Maclean, D. J., and Irwin, J. A. 1995. Phytophthora sojae avirulence genes, RAPD, and RFLP markers used to construct a detailed genetic linkage map. Mol. Plant Microbe Interact. 8:988-995.
Xue, A. G., Marchand, G., Chen, Y., Zhang, S., Cober, E. R., and Tenuta, A. 2015. Races of Phytophthora sojae in Ontario, Canada, 2010-2012. Can. J. Plant Pathol. 37:376-383.

Yan, H., and Nelson, B., Jr. 2019. Adaptation of Phytophthora sojae to Rps resistance genes over the past two decades in North Dakota. Plant Health Prog. 20:88-93. 